\title{
Architectural Education and
}

\section{Community Power: \\ Teaching Design Participation and Community \\ Technical Aid}

\author{
TOM WOOLLEY \\ Queen's University Belfast \\ United Kingdom
}

\begin{abstract}
Architectural Education in the UK has drifted toward an esoteric preoccupation with style and artistic production and is ignoring important issues of society and urban change. Techniques of user participation and involvement of students in real life social problems is on the agenda in only a few schools of architecture. Yet in the real world more emphasis is being placed on tenants and resident participation in social housing programmes. The Community Technical Aid movement is going from strength to strength. However UK schools of architecture are not preparing students for work of this kind. In this paper it is argued that architectural history and theory is largely to blame for placing too much emphasis on precedent studies divorced from social and political context. Progressive movements in CIAM and radical social programmes are ignored in favour of pre-occupation with fashionable but content free stylisms.
\end{abstract}

\section{INTRODUCTION}

In this paper I will attempt to contrast my own attempts to teach architecture from a position of social and political engagement with the more widespread and fashionable approach (in the UK) of design as a self indulgent activity insulated from the realities and rigours of the real world. Recently we had a visit to Belfast from Frank Duffy, the RIBA President, who was visiting 6 UK Schools of Architecture to discuss his strategic study of the profession. The results of these visits will shortly be published in the RIBA Journal and should reveal a wide range of attitudes to the problems facing the architectural profession in the UK today. At Queen's we try to confront these problems head on. Students work on a range of projects that allow them to understand the real difficulties they will face when attempting to practise imaginative design in a tough world of fee cutting, project management and a range of clients concerned only with short term utilitarian cheapness. At the Bartlett (University College London) which Frank Duffy and his colleagues had visited a few days before, the approach was totally different. He characterised both staff and students at the Bartlett as being like ostriches with their heads in the sand. They were doing things, in their view, far more important than dealing with the mundane, boring issues of getting things built. The contrast with Queen's could hardly have been more marked.

This polarisation typifies the current situation in the UK. Students flock to the Bartlett which sees itself as a centre of excellence for imaginative design. Many of the schools in the South East of England ape the Bartlett/AA approach whereas on the periphery, in the regions (with the exception of the MacIntosh in Glasgow), most of us try to maintain a balance between design as an organic process responding to clients, users, context and culture and building, technology and the environment. "Worthy but dull" is how we are seen by our critics. We are doing 'building' as opposed to 'Architecture'. The same insult was regularly thrown at my work at the AA in the 1970s. My commitment to social responsibility was seen by the AA avant-garde of the time as humourless whilst they were concerned with irony and the architectural joke. Style was in, social responsibility was out.

I characterise the Bartlett approach as one of decadence. It seems entirely appropriate that in the dying days of the Thatcherite era, dominated by selfishness and competition, public corruption and an abuse and exploitation of the environment and community, the elite in the architecture schools in and around London (for this is how they see themselves) should be engaged more and more in a self indulgent fantasy world, while in Belfast we have the opportunity to respond to the enormous political challenges thrown up by the cease fire and the prospect of a long term peace.

\section{THE ARCHITECTURE OF DECADENCE}

Much architectural thinking and writing is distinguished by its intellectual sloppiness. This is exemplified in a recent book entitled 'Educating Architects' ${ }^{1}$ published by Academy Editions. This book contains many articles which typify the shallow self indulgent approach to architecture which I am critical of. One only needs to dip into any page (with a few notable exceptions) to come up with a jumbled up rag bag of pseudo intellectual ideas which purport to give some rationale to architectural fantasy making. For example:- 
These four (sic) principles: connection and heterogeneity; multiplicity; a-signifying rupture, cartography and decalcomania, provide a useful model for architectural education today. ${ }^{2}$

and

students seek to be the creators of the avant-garde itself in a constant striving to change perceptions and recreate the world often at the margins of what might traditionally have been considered the edges of the architectural project. ${ }^{3}$

It may appear to be very conservative to critcise the blind pursuit of the avant-garde - at the edges and often over the edge, of what I recognise as relevant to architecture. But in my view the studio becomes an endless performance of the Emperor's New Clothes. What is hung on the wall is so obscure or absurd that it is praised without understanding.

This endless pursuit of crazy novelty rapidly descends into the banal. What is more disturbing is that the self indulgent, architecture as art, abstracted from real life, is frequently propped up by reference to philosophical and theoretical writing, which is in itself, like the architectural drawings it justifies, a collage of words thrown together with little thought of understanding. Take Dalibor Vesely, for instance: "The role of mimesis in the process of making reveals the mystery of order as a tension between the potential and actual existence of order, which in its ultimate form always points towards the ultimate order - the cosmos." 4

Vesely in this convoluted and bizarre piece of writing is trying to produce a critique of culture determined by technological change. He argues instead for a non-instrumental approach, one of "ambiguity, tension and conflict" - in effect total confusion, a strange approach from someone who uses the word 'order' so frequently in his texts. Vesely and many others constantly put art, the spontaneous process of creation always intellectually just beyond our reach. That is for most of us. The inner circle who can indulge in such esoteric banter provide the amoral climate in which self indulgent artistic production in architecture schools is encouraged.

A cultural framework that is grounded in the realities of the modern world and grapples creatively with the problems of global warming, third world poverty, the rise of nationalism and fascism and religious fundamentalism are left at the door of the school of architecture. They do not want these 'trivial' issues to get in the way of fostering imagination and design talent.

The end product of this approach finds an expression in the annual exhibition of prize winning work at the RIBA. The Presidents' medals are chosen each year from submissions from most schools of architecture though some schools rarely bother to submit student work any more. If our students have spent their final year crafting a beautiful building to solve architectural problems on the Peaceline in Belfast, or the needs of Aids patients or a theatre in a run down part of Dublin, they will have resolved questions of urban context, structural form, access for the disabled and made their presentation legible for any lay observer. Our end of year exhibition is open to the Belfast public. Such criteria inevitably eliminate our students' work from the Presidents' Medals Exhibition where prize winners are selected by members of the esoteric elite in the South East of England.

Take for instance the silver medal runner up in 1992, published in Building Design, a project entitled 'Lovable Satin Charms: Berlin Outcrop.' ${ }^{5}$ The designs were for a series of 'urban caves' splattered across Berlin with no apparent concern for context, use or impact on the existing structure of the city. The published judges comments included the following:

Elia Zenghelis: One wonders whether the student benefited or it even benefited the city. It could be of value to the city but only after a second, not intended reading.

and

Amanda Levete: Actuallynoneofus reallyunderstood it.

This charming and curious approach to architectural education causes a great deal of angst to our students. On the one hand they want to be good Designers, on the other they want a portfolio of work that will get them a job in a local office where design (with a very small $d$ ) is barely on the agenda.

However the avant-garde trend setting leaders of fashion in the South East do eventually get things built. Our students see Co-op Himnelblau or Zaha Hadid as heroes and their forms are inevitably copied and turn up in real buildings years later. Northern Ireland has always been in an architectural stylistic time warp so we are still seeing the construction of third rate post modern facades and houses long after it became passé in England. As the international style magazines increasingly dominate the thinking of our students it becomes harder and harder to get them to ground their designs in the social and cultural reality of Northern Ireland that might lead to a genuine local distinctiveness. ${ }^{6}$

One way to approach this problem is to teach Principles of Design where the emphasis on architecture grows from genuine cultural and political engagement rather than self indulgent fantasy. This involves an alternative approach to the history of modern architecture.

\section{THE ARCHITECTURE OF SOCIAL ENGAGEMENT}

Much teaching of history and theory of architecture, in the UK at least, has been distinguished by an absence of scholarship and rigour in recent years. Many of the accounts of the development of modern architecture have divorced form from content and present a view of changing styles to students as though architects have the freedom to choose from whatever they like.

The greatest weaknesses of general accounts of modern 
architecture is their failure to distinguish between the international style and its utilitarian reproduction as a cheap developer's architecture and the socially committed architecture of the genuine pioneers of modernism. ${ }^{7}$ There is no space here to rehearse these arguments but they are easily found in the debates that went on at the CIAM conferences in the 1950 s.

My approach is simply to introduce the students to the lesser known architects of the modern movement from Arts and Crafts through the expressionists to the humanists like Giancarlo De Carlo, Ralph Erskine and others. A study of these architects reveals a very strong link between their design ideas and their (largely left wing) ideas about politics and society. Connections can be made between the garden city movement and Unwin, Berlage in Netherlands and Ernst May in Frankfurt where social reform, political change and urban design were intermeshed. There are also fascinating connections between the influence of Rudolf Steiner and his early ecological thinking and Mendelsohn, Taut, Scharoun and many others that laid the foundations of organic architecture.

Much of this history was suppressed and ignored in the superficial dismissal of modernism by Charles Jencks. ${ }^{8}$ The baby of social responsibility and user responsiveness as a cornerstone of modern design was thrown out with the bath water of Pruitt Igo and the supposed demise of the international style.

Fortunately a revival of interest in socially committed architecture, Giancarlo De Carlo ${ }^{9}$ and Hannes Scharoun ${ }^{10}$ and important exhibitions in London has led to a reappraisal of the richness of many architects during the early half of the 20 th century who were otherwise destined for a mere quirky footnote in the major texts. ${ }^{11,12}$

In a fascinating chapter in Nils Prak's important book, 'Architects: the Noted and the Ignored', ${ }^{13}$ he prints a table showing the length in the number of printed columns devoted in key texts to important modern architects. Reputation based on publication in glossy magazines has become paramount, he argues and this has established a culture of hero worship and valuing of 'great' architecture which is based on the esoteric views of the architectural audience which is often directly opposed to the views of ordinary people. Such a view is confirmed by Diane Ghirardo who has shown how much architectural discourse is essentially "self serving. ${ }^{14}$

Today students acquire much of their appreciation of architecture, not from visiting and experiencing buildings, or a rigorous analysis of their successful functioning, but a relatively superficial glance at images in the glossies. While I do not dispute that much can be learnt from the 'noted' architects, such architecture must be visited and interpreted; understood in its social context. Recent Queen's field trips involved staying at $\mathrm{La}$ Tourette to understand and experience Corbusier, visiting Aalto's work in Finland and studying the architecture that followed. Other students recently visited Lucien Kroll's office and went to the medical faculty at Louvain.

We try to show that these architectural forms emerged from attempts to change and improve social conditions in many cases and that the commissioning of innovative design was possible because of a cultural and economic context that encouraged good buildings.

\section{USING LIVE PROJECTS}

While many of our students and some of my colleagues feel there is a place for self indulgent fantasy in the choice of studio projects, this is balanced by work, which encourages creative and imaginative design, but is grounded in a real life context. This allows the students an opportunity to explore the contradictions and conflicts in trying to produce good quality architecture in a society where good design is low on the agenda. They also need to learn that even though there is a lot of bad architecture produced through poor design, cost cutting etc, many ordinary people are actually very concerned about the quality of the environment.

There are two main ways currently used to tackle these issues. Firstly Level 2 students, who attend a 'professional skills' class, go out and interview lay people about their views on architecture and the environment. Last year it was voluntary and self help groups. Contacts made during these visits have led to some potential live projects. This year more emphasis has been put on sustainability and green issues and the students had to interview people who had recently built themselves new houses in the Northern Ireland countryside. Level 3 students who attend the Principles of Design class have to write a critque of an event in the Queen's Arts Festival and they answer exam questions about the relationship between architectural ideas and the social and political context in Northern Ireland.

In the studio students spend some of their time working on projects that genuinely bring them into contact with user groups and community issues and problems. This is something based on experience at the AA in the 1970s and Hull School of Architecture for part of the 80s.

Crucially such work must involve the students in identifying the problems and writing briefs with local people. Simply choosing a real issue and asking the students to design solutions without going through the problem identification stage is merely teaching them how to do things without understanding how to decide what should be done. ${ }^{15}$ Examples of projects in Belfast include analysing the needs of a small town (Downpatrick) and engaging in the controversy surrounding road clearance proposals. The students' exhibition challenged local politicians, but helped to give confidence to local people fighting the road proposals. ${ }^{16}$ In another project, Crossgar, a typical Northern Ireland village, students spent an intensive week drawing up sketch proposals for a range of needs in the village from environmental improvements, alterations to the exisiting village hall and designs for an integrated school. The integrated school will provide primary education for people who do not want their children to go to segregated Catholic and Protestant schools. One group of students identified a row of derelict buildings 
which could be converted into a local library and resource centre, but the developer who owned the site has decided to demolish and build mock Georgian town houses instead.

This sort of local engagement at least creates the opportunity for students to make the connection between their efforts to become good designers and the real world that often spurns good design. Much of the need for good design from self help and community groups remains un-met and has sustained the Community Technical Aid Network (ACTAC) throughout the UK ${ }^{17}$. We are holding discussions with Community Technical Aid Northern Ireland about regular student involvement in actual projects as a specialist option in postgraduate education at Queen's. There are many skills to learn in participatory design, listening, organising and facilitation on top of design and technical expertise. The technical aid network with its 70 members provides a wealth of opportunities for collaboration in live projects and yet most schools of architecture (with the notable exception of Cardiff, Bath and Birmingham) ignore these opportunities.

It is hard to know whether students at Queen's are more pre-disposed to social responsibility than students at the more fashionable metropolitan schools. When Belfast students won their turn to organise the annual 'Winter School', speakers ranged from fashionable designers such as Odile Decq to green architects like Christopher Day ${ }^{18}$. Student initiated projects included the design of a women's centre in a run down loyalist area with members of Matrix and an environmental scheme on the peace line in a nationalist housing estate in West Belfast with Berlin Landscape Architect Gabrielle Lanzrath.

Students have also had the opportunity to wrestle with political and cultural differences working on the Mary Robinson Award designing accommodation for travellers and some got to meet the President as well as travellers on impoverished roadside sites.

Recent studies of green issues involved travelling to Dublin to meet the Lord Mayor, John Gormley who is a member of the Green Party.

\section{ALTERNATIVE TEACHING METHODS}

Closely linked with teaching through live projects and relating architecture to contemporary cultural and social attitudes is the need to change the conventional studio/crit culture.

For many years I have fought against the oppressive and negative crit system in which students' designs are pinned on the wall and then aggressively pulled apart by arrogant critics. Such an approach to teaching seems to go hand in hand with the self serving, self indulgent approach to architecture that I condemned at the start of this paper. Such a destructive approach destroys the self confidence and creative ability of many good students and is designed to ensure the survival, not so much of the fittest, but those best able to bullshit their way through school.
The defensiveness engendered by the conventional crit system lead on to the arrogance, poor listening abilities and anti-participation views which form the basis of much public criticism of architects. Thus I fight against conventional crits, not only in a humanitarian attempt to protect the sanity of students but to support students' development of participatory skills. ${ }^{19}$

There are many techniques for turning crits into a more positive experience. The appearance of real clients from community groups in the school of architecture being one of the best. This turns the discussion into a really genuine conversation about the merits and weaknesses of a student proposal. The drawings and presentation need to be understandable and the normal arrogant point scoring of the architectural critic becomes irrelevant.

There is need for increasing emphasis in architectural education on 'green' issues. This is not easy in Northern Ireland where awareness of the environmental impact of buildings is at a very low level. The damage of global warming, water table pollution, over extraction of natural resources and waste disposal is as serious in Ireland as anywhere. Planning policies permit erection of badly designed bungalows throughout the countryside ${ }^{20}$ even in areas of great scenic beauty and environmental sensitivity.

Much of the heritage of old stone houses and industrial buildings is being enthusiastically swept away and it is hard to persuade colleagues that design skills can be taught through conversion and rehabilitation projects.

Some students have enthusiastically embraced the green agenda however and some even help to build the Professor's ecological house! As David Pearson wrote in $\mathrm{AR}^{21}$ quoting a Professor of Architecture at Columbia University New York in 1947: "He saw the architect as being predominantly form conscious failing to establish a holistic design synthesis using all the human senses."

This paper is essentially a polemic with some anecdotal material on attempts to teach architecture in a holistic way. By confronting students with the real world, far from suppressing their creative talents, new creative energy to put the world to rights are released.

I make no apologies from steering them away from the self indulgent esoteric ploys of the Bartlett and the AA and hope that they will make a stronger contribution to a more peaceful, participative, sustainable Ireland in the future.

\section{REFERENCES}

Pearce $\mathrm{M}$ and Toy M (Eds), Educating Architects, AD Academy Editions 1995.

${ }^{2}$ Op cit - Introduction page 7.

${ }^{3}$ Op cit - Introduction page 7.

4 Vesely D in Pearce M and Toy M (Eds), Educating Architects, AD Academy Edition 1995, page 44.

s Building Design, 'Presidents Medals Silver Awards', pages 1213, December 111992.

${ }^{6}$ Clifford S and King A (Eds), Local Distinctiveness Place, Particularity and Identity, Common Ground London 1993. 
${ }^{7}$ Nuttgens P, The Story of Architecture, Phaidon 1983 (for example).

${ }^{8}$ Jencks C, Post Modernism - The New Classicism in Art and Architecture, Academy Editions, London, 1987.

9 Zucchi B, Giancarlo de Carlo, Butterworth Architecture 1992.

${ }^{10}$ Blundell Jones P, Hannes Scharoun, Phaidon Press, 1995.

1 Pevsner N, Pioneers of Modern Design, Penguin 1960.

${ }^{12}$ Frampton K, Modern Architecture, A Critical History, London: Thames \& Hudson 1980.

${ }_{13}$ Prak N, Architects the Noted and the Ignored, Wiley J and Sons 1984, Chapter 6, Architects and their Belief Systems.

${ }^{14}$ Ghirardo D, Out of Site - A Criticism of Architecture, Bay Press 1991. is Rappoport A, Studious Questions, Architects Journal 26.10.93.

${ }^{16}$ Mackel C and Woolley T (Eds), Downpatrick, Beyond the Door, Queen's University Belfast 1993.

${ }^{17}$ ACTAC (The Technical Aid Network) Directory 1995. Available from ACTAC, 64 Mount Pleasant, Liverpool, L3 5SD.

${ }^{18}$ Day C, Places of the Soul. C Day is the Tyrone Brick Visiting Professor at QUB.

19 Woolley T, Why Studio? Architects Journal, 20.3.91.

${ }^{20}$ Woolley T, Bungalow Blight: An Ecological Response CIB, Building Research Establishment, Watford, May 1995.

${ }^{21}$ David Pearson, Making Sense of Architecture, Architecture Review, October 1994. 